\title{
PERILAKU PENGGUNAAN TAS BELANJA PADA IBU RUMAH TANGGA TIDAK BEKERJA DALAM PERSPEKTIF THEORY OF PLANNED BEHAVIOR
}

\author{
Ludhini Volva*), Moh. Djemdjem Djamaludin \\ Departemen IImu Keluarga dan Konsumen, Fakultas Ekologi Manusia, Institut Pertanian Bogor, \\ Bogor, 16680, Indonesia
}

"Email: ludhini.volva@gmail.com

\begin{abstract}
Abstrak
Penggunaan tas belanja merupakan salah satu perilaku ramah lingkungan yang perlu didorong untuk mengurangi jumlah sampah plastik. Penelitian ini bertujuan untuk menganalisis pengaruh karakteristik ibu, sikap terhadap perilaku, norma subjektif, kontrol perilaku, dan niat terhadap perilaku penggunaan tas belanja dengan menggunakan Theory of Planned Behavior. Penelitian ini menggunakan desain cross sectional study dengan lokasi penelitian yang dipilih secara purposif sebagai perwakilan wilayah perdesaan dan wilayah perkotaan. Contoh dalam penelitian ini adalah 100 ibu rumah tangga yang tidak bekerja. Data dikumpulkan melalui wawancara dengan menggunakan kuesioner terstruktur. Hasil penelitian menunjukkan bahwa sikap terhadap perilaku, norma subjektif, kontrol perilaku, dan niat ibu tidak bekerja dalam menggunakan tas belanja sudah terkategori cukup tinggi. Hasil uji regresi menunjukkan bahwa kontrol perilaku berpengaruh positif signifikan terhadap niat. Hasil uji regresi lainnya menunjukkan bahwa frekuensi penggunaan tas belanja dipengaruhi secara positif oleh niat, norma subjektif, dan kontrol perilaku namun dipengaruhi secara negatif oleh sikap terhadap perilaku.
\end{abstract}

Kata kunci: kontrol perilaku, niat, norma subjektif, sikap terhadap perilaku, tas belanja.

\section{Behavioral Analysis Of Reusable Shopping Bag Usage Of Housewives Using In Perspective Of Theory Of Planned Behavior}

\begin{abstract}
The usage of reusable shopping bag is one of pro-environmental behavior which needs to be encouraged to reduce plastic waste. This research aimed to analyze the influence of sample characteristic, attitude towards behavior, subjective norm, perceived behavioral control, and intention towards the usage behavior based on the theory of planned behavior. This research used cross-sectional design. The purposively selected locations were Cijujung Village and Panaragan Village which represent village and city area respectively. The sample in this research were 100 non-working housewives. The results showed that attitudes towards behavior, subjective norms, perceived behavioral control, and intention was in the moderate category. The result of regression test showed that the perceived behavioral control had a significant positive effect towards intention. The other result of regression test showed that the frequency of use is influenced positively by intention, subjective norms, and perceived behavioral control meanwhile it is affected negatively by the attitude towards behavior.
\end{abstract}

Keyword: attitude towards behavior, intention, perceived behavioral control, reusable shopping bag, subjective norm.

\section{PENDAHULUAN}

Indonesia merupakan salah satu negara yang mengalami permasalahan lingkungan hidup yang cukup serius, khususnya mengenai sampah. Total jumlah sampah di Indonesia pada tahun 2019 diperkirakan akan mencapai 68 juta ton (Dirjen PSLB3, 2016) dan sampah plastik memiliki proporsi 14 persen dari total sampah yang dihasilkan. Hal ini didukung oleh penelitian Jambeck (2015) yang menyatakan bahwa Indonesia menempati urutan ke-2 sebagai negara penghasil sampah plastik terbesar di dunia setelah Tiongkok.
Permasalahan ini menjadi perhatian serius karena sampah plastik memiliki banyak dampak negatif. Menurut Surono (2013) plastik memiliki dampak positif dan negatif, dampak positif disebabkan plastik memiliki kelebihan dibandingkan barang yang lainnya, seperti plastik tahan karat, lebih kuat, ringan, fleksibel, mudah diberi warna dan dibentuk, tidak mudah pecah, serta menjadi isolator panas dan listrik yang baik. Sementara itu, dampak negatif yang ditimbulkan diantaranya sampah plastik tidak dapat terutai dengan cepat sehingga menyebabkan kesuburan tanah akan berkurang, dan sampah plastik yang dibuang 
sembarang dapat menyumbang aliran air sehingga menyebabkan terjadi banjir, serta sampah plastik yang dibakar akan menyebabkan timbulnya zat-zat berbahaya bagi kesehatan manusia.

Sampah plastik sulit terurai dibandingkan dengan sampah lainnya (Ditjen PSLB3, 2016). Pembuangan sampah plastik ke laut mengancam kehidupan 1 juta binatang laut setiap tahunnya (Ditjen PSLB3, 2016). Selain itu, pembakaran sampah plastik dapat berkontribusi terhadap pemanasan global. Sebanyak 80 persen ibu rumah tangga membuang sampah plastik di kebun sekitar rumah dan membakar sampah plastik di sekitar rumah (Setyowati \& Mulasari, 2013). Permasalahan sampah plastik yang jumlahnya semakin meningkat apabila tidak diatasi akan cenderung menyebabkan pencemaran lingkungan sehingga dibutuhkan upaya untuk mengurangi sampah dengan cara mendaur ulang sampah menjadi sumber energi dan barang-barang yang lebih bermanfaat (Purwaningrum, 2016). Oleh karenanya, perlu adanya upaya untuk mengurangi jumlah sampah plastik, salah satunya dengan membawa tas belanja.

Penggunaan tas belanja merupakan salah satu perilaku ramah lingkungan yang telah direkomendasikan oleh berbagai pihak atau seringkali dikenal sebagai salah satu bentuk perilaku prolingkungan. Tujuan direkomendasikannya penggunaan tas belanja adalah mengurangi jumlah sampah plastik yang dihasilkan. Sebanyak lima tas belanja yang rutin digunakan satu minggu sekali dapat menggantikan 520 lembar kantung plastik (Gamerman, 2008). Hasil penelitian lain menyebutkan bahwa perilaku penggunaan tas belanja dan faktor yang berpengaruh terhadap pemakaian tas belanja dapat mendorong pemakaian tas belanja (Yeow et al., 2014; Lam \& Chen, 2006). Selain itu, penggunaan tas belanja dapat memengaruhi perilaku ramah lingkungan lainnya seperti meningkatkan pembelian makanan organik ramah lingkungan (Karmarkar \& Bollinger, 2015).

Berdasarkan hasil penelitian Steg dan Vlek (2009), pertimbangan biaya dan manfaat merupakan salah satu faktor internal yang memengaruhi keputusan berperilaku ramah lingkungan. Selain itu, besarnya pengaruh norma deskriptif dan normatif memengaruhi perilaku tergantung pada atribut yang mencolok pada suatu norma tertentu. Menurut Kusumo et al. (2017) menyatakan bahwa masyarakat di Indonesia cenderung lebih memerhatikan norma atau memandang yang harus dilakukan ketika berada di lingkungan masyarakat. Sementara hasil penelitian Wijaya (2017) menunjukkan bahwa kelompok referensi, anggota keluarga, rekan ataupun media menjadi stimulus konsumen dalam merespon pembelian produk ramah lingkungan. Beberapa kajian tentang faktor yang memengaruhi konsumen berperilaku hijau seperti pengetahuan tentang ramah lingkungan, sikap konsumen tentang ramah lingkungan (Teng et al., 2012; Wahid et al., 2011). Pada penggunaan tas belanja, Yeow et al. (2014) mengungkapkan bahwa faktor sikap dan kontekstual memengaruhi perilaku sehingga intervensi bisa dilakukan dengan memberikan informasi untuk mengubah sikap dan menghapus kendala konteksual. Kusumo et al. (2017) menunjukkan bahwa pengetahuan, sikap, dan keinginan konsumen yang ditunjukkan melalui variabel sikap diharapkan akan mendorong konsumen untuk berperilaku ramah lingkungan.

Penelitian ini bertujuan mengkaji perilaku penggunaan tas belanja pada ibu rumah tangga dengan menggunakan landasan Theory of Planned Behavior (TPB) sebagai dasar analisis. Menurut Ajzen, (1991; 2002), TPB adalah teori yang menekankan kepada niat individu untuk menampilkan suatu perilaku tertentu. Niat dianggap dapat melihat variabel motivasi yang memengaruhi perilaku dan indikasi besarnya usaha seseorang untuk mencoba. Teori ini mengunakan tiga variabel yang menentukan niat, yaitu sikap terhadap perilaku, norma subjektif, dan kontrol perilaku. Penelitian Pratiwi dan Hartoyo (2014) menemukan bahwa adanya hubungan positif yang signifikan antara nilai dan pengetahuan keuangan dengan tiga komponen utama pembentuk niat dalam Theory of Planned Behavior (sikap terhadap asuransi jiwa, norma subjektif, dan kontrol perilaku yang dirasakan), hal ini juga berarti semakin baik sikap terhadap asuransi jiwa, semakin besar norma subjektif, dan semakin besar kontrol perilaku yang dirasakan oleh mahasiswa maka semakin besar pula niat beli asuransi jiwa yang dimiliki mahasiswa.

Hasil penelitian Dewi dan Yusalina (2011) dengan menggunakan modifikasi dari Theory Planned of Behavior (TPB) menunjukkan konsumen di Kota Bogor memiliki motivasi tinggi dan sikap positif terhadap konsumsi beras organik, mengkonsumsi beras organik dua kali seminggu di rumah dan beberapa kali setahun di luar rumah. Penelitian lain dengan menggunakan TDP menunjukkan sikap 
terhadap perilaku, norma subjektif, perilaku control secara positif memengaruhi niat perilaku (Handayani, 2011). Selain itu, model TPB dapat dengan baik menjelaskan perilaku yang prolingkungan seperti pada penelitian Han, Hsu, dan Sheu (2010) yang menemukan sikap, norma subyektif, dan kontrol perilaku yang dirasakan secara positif mempengaruhi niat untuk menginap di hotel hijau. Penggunaan teori ini juga didasarkan pada asumsi bahwa konsumen sulit terlibat dalam suatu perilaku yang sangat dipengaruhi oleh kontrol perilaku. Hal ini telah dibuktikan oleh hasil penelitian dari Hasan (2015) yang menunjukkan bahwa perilaku ekologis sangat dipengaruhi oleh perceived behavior control atau kontrol perilaku yang dirasakan. Kajian ini menjadi menarik untuk diteliti lebih lanjut pada daerah perkotaan dan perdesaan karena berdasarkan studi yang dilakukan oleh Huddart-Kennedy et al. (2009) dan Berenguer et al. (2005), terdapat perbedaan perhatian, nilai, sikap, dan perilaku prolingkungan diantara individu yang tinggal di perkotaan dan perdesaan. Hasil penelitian Chen et al. (2011) menyebutkan terdapat perbedaan juga di antara perilaku prolingkungan individu berdasarkan status pekerjaanya.

Penelitian mengenai tas belanja telah dilakukan oleh Nawangpalupi, Pratiwi, dan Herawati (2011) dengan tujuan mengidentifikasi proses perubahan perilaku konsumen dari penggunaan kantung plastik belanja ke penggunaan tas belanja yang dipakai ulang. Hasil penelitian tersebut menemukan bahwa responden yang berkomitmen untuk mengurangi penggunaan kantung plastik masih relatif rendah dibandingkan keseluruhan responden yang mengambil mata kuliah, kondisi ini disebabkan karena responden malas dan terkadang lupa tidak membawa tas belanja.

Oleh karena itu, penelitian mengenai analisis perilaku penggunaan tas belanja pada ibu rumah tangga yang tidak bekerja menggunakan perspektif TPB menjadi penting untuk dilakukan untuk dapat menemukan pengaruh sikap, norma subjektif, dan kontrol perilaku dalam membentuk niat dan perilaku ibu tidak bekerja menggunakan tas belanja yang dipakai ulang. Berdasarkan uraian diatas, maka tujuan penelitian ini adalah untuk: 1) mengidentifikasi karakteristik responden, perilaku penggunaan, sikap terhadap perilaku, norma subjektif, kontrol perilaku, dan niat menggunakan tas belanja pada responden; 2) menganalisis perbedaan karakteristik responden, perilaku penggunaan, sikap terhadap perilaku, norma subjektif, kontrol perilaku, dan niat berdasarkan wilayah dan penggunanya; 3) menganalisis faktor yang memengaruhi niat untuk menggunakan tas belanja; dan 4) menganalisis faktor yang memengaruhi perilaku penggunaan tas belanja.

\section{METODE PENELITIAN}

Penelitian ini menggunakan desain penelitian cross sectional study. Pemilihan tempat dalam penelitian ini dilakukan secara purposif berdasarkan kemudahan akses dengan pasar. Pengambilan data penelitian dilakukan di dua kelurahan yang ada di wilayah perkotaan Bogor yang dekat dengan pasar mengingat penelitian ini ingin mengkaji penggunaan tas belanja. Dua kelurahan yang dipilih masingmasing mewakili wilayah perkotaan dan perdesaan.

Populasi dalam penelitian ini adalah seluruh ibu rumah tangga tidak bekerja yang berada di kedua kelurahan terpilih. Kerangka contoh dalam penelitian ini adalah ibu rumah tangga tidak bekerja di RW terpilih di masing-masing kelurahan. Pemilihan contoh dilakukan pada tingkat RW dikarenakan jumlah ibu rumah tangga tidak bekerja pada level RT tidak mencukupi untuk dilakukan pemilihan contoh secara acak. Contoh dipilih secara acak dari kedua RW terpilih sebanyak 100 orang dengan rincian 40 contoh dari RW yang berada di kelurahan yang mewakili wilayah perkotaan dan 60 contoh dari RW yang berada di kelurahan yang mewakili wilayah perdesaan. Contoh dari kerangka contoh di masingmasing RW dipilih secara acak proporsional dengan mempertimbangkan jumlah populasi yang berbeda antara RW wilayah perkotaan dan perdesaan terpilih.

Pengukuran variabel TPB pada penelitian ini diadopsi dari instrumen Laudenslager et al. (2004). Instrumen pada variabel sikap terhadap perilaku memodifikasi instrumen dari Lam dan Chen (2006). Instrumen perilaku memiliki nilai Cronbach's alpha sebesar 0,713. Pengukuran variabel norma subjektif menggunakan instrumen yang diadopsi dari Yeow et al. (2014) dengan nilai Cronbach's alpha sebesar 0,602. Pengukuran variabel kontrol perilaku, niat, dan perilaku menggunakan instrumen yang diadopsi dari instrumen Ohtomo dan Ohnuma (2014) dengan nilai Cronbach's alpha sebesar 0,634 untuk kontrol perilaku dan niat sebesar 0,604. Pengukuran variabel dalam theory of planned behavior pada penelitian ini tidak 
menggunakan 2 dimensi, yaitu keyakinan berperilaku dan evaluasi hasil pada variabel sikap; keyakinan normatif dan motivasi untuk mengikuti pada variabel norma subjektif; keyakinan dan kekuatannya pada variabel kontrol perilaku). Variabel sikap terhadap perilaku, norma subjektif, dan kontrol perilaku kemudian disesuaikan dengan ketentuan pengukuran yang terdapat dalam guideline pembuatan instrumen Theory of Planned Behavior (Ajzen, 2006). Data yang terdapat pada variabel sikap terhadap perilaku, norma subjektif, kontrol perilaku, dan niat diukur menggunakan dengan 4 skala Likert jawaban. Sementara itu, data yang terdapat pada variabel perilaku penggunaan diukur melalui frekuensi penggunaan tas belanja ketika berbelanja yang menggunakan jawaban 4 skala Likert.

Pengolahan data dilakukan dengan menggunakan program Mirosoft Excel dan Statistical Package for The Social Science (SPSS). Pada penelitian ini, skala data yang digunakan dalam variabel sikap terhadap perilaku, norma subjektif, kontrol perilaku, dan niat adalah ordinal. Pada variabel perilaku, skala ordinal digunakan untuk mengukur frekuensi penggunaan; skala rasio digunakan untuk mengukur frekuensi belanja, jumlah tas belanja, dan durasi penggunaan tas belanja; sementara skala nominal digunakan untuk mengukur kepemilikan, sumber informasi, lokasi informasi, dan motivasi.

Analisis deskriptif yang dilakukan dalam penelitian ini bertujuan mengidentifikasi karakteristik responden dan variabel dalam perspektif TPB meliputi frekuensi, rata-rata, standar deviasi serta nilai minimum dan maksimum. Pada data yang dihasilkan dari skala data ordinal, dilakukan transformasi ke dalam bentuk indeks (0-100). Selanjutnya, pada variabel sikap terhadap perilaku, norma subjektif, kontrol perilaku, dan niat dikategorikan menjadi tiga kelas (rendah, sedang, dan tinggi) berdasarkan perhitungan interval kelas. Pengategorian rendah: Skor minimal sampai (Skor minimal+interval kelas), sedang: (Skor minimal+interval kelas)+1 sampai (Skor minimal+ 2 kali interval kelas), dan tinggi: (Skor minimal+ 2 kali interval kelas sampai Skor maksimal). Data pada variabel usia dikategorikan berdasarkan Hurlock (1980), data pada variabel pendidikan dikategorikan menjadi 7 kategori, yaitu 1) tidak sekolah, 2) tidak tamat SD, 3) tamat SD, 4) tamat SMP, 5) tamat SMA, 6) D1/D2/D3, 7) D4/S1). Data pada variabel pendapatan dikategorikan menjadi 4 kategori, yaitu 1) <
Rp.1.000.000 2) Rp1.000 000 - Rp2.000.000 3) $\mathrm{Rp2} .000 .001$ - Rp3.000.000 4) > Rp3.000.000.

Analisis inferensia dilakukan dengan uji beda, regresi linear berganda, dan regresi logistik ordinal. Uji beda dilakukan terhadap karakteristik contoh dan variabel dalam TPB antara contoh yang tinggal di wilayah perkotaan dan perdesaan. Uji regresi linear berganda ditujukan untuk menguji pengaruh karakteristik contoh, sikap terhadap perilaku, norma subjektif, dan kontrol perilaku terhadap niat menggunakan tas belanja. Uji regresi logistik ordinal digunakan untuk menguji pengaruh karakteristik contoh, sikap terhadap perilaku, norma subjektif, kontrol perilaku, dan niat terhadap perilaku penggunaan tas belanja.

\section{HASIL PENELITIAN}

\section{Karakteristik Ibu}

Hasil penelitian menunjukkan bahwa hampir separuh ibu $(48,0 \%)$ berada pada kategori usia dewasa madya dengan rata-rata usia ibu adalah 44,72 tahun. Selain itu, hasil lain juga menunjukkan bahwa empat dari sepuluh ibu $(41,0 \%)$ memiliki pendapatan keluarga yang bekisar antara Rp1.000.000,00Rp2.000.000,00 dengan rata-rata pendapatan keluarga adalah sebesar Rp2.163.500,00/bulan. Berdasarkan hasil identifikasi tingkat pendidikan, proporsi terbesar yaitu masing-masing sepertiga ibu merupakan lulusan SD dan SMA dengan ratarata lama pendidikan yang ditempuh ibu dalam penelitian ini adalah selama 9,40 tahun.

\section{Perilaku Penggunaan Tas Belanja}

Hasil penelitian menjelaskan bahwa sebagian besar ibu memiliki tas belanja dengan persentase di wilayah perdesaaan lebih kecil dibandingkan di wilayah perkotaan, yaitu 70,0 persen untuk wilayah perdesaan dan 85,0 persen untuk wilayah perkotaan. Selain itu, hasil penelitian juga menunjukkan bahwa sebanyak 51,7 persen ibu di wilayah perdesaan dan 35,0 persen ibu di wilayah perkotaan tidak pernah menggunakan tas belanja sedangkan. Sebagian besar ibu menggunakan satu tas belanja dengan proporsi 80,0 persen untuk ibu di perdesaan dan 76,9 persen untuk ibu di perkotaan.

Hasil penelitian juga menunjukkan bahwa $46,7 \%$ ibu di perdesaan dan $53,8 \%$ ibu di perkotaan menggunakan tas belanja sejak tahun 2016. Sepertiga ibu di perdesaan 
$(33,3 \%)$ mendapatkan informasi mengenai tas belanja dari media sedangkan 57,7 persen ibu di perkotaan mendapat informasi dari supermarket. Hasil penelitian juga menunjukkan adanya perbedaan dalam hal tempat penggunaan tas belanja oleh ibu tidak bekerja di wilayah perdesaan dan di perkotaan. Sekitar lima dari sepuluh ibu di perdesaan $(53,3 \%)$ menggunakan tas belanja di pasar sedangkan sekitar delapan dari sepuluh ibu di perkotaan (88,5\%) menggunakan tas saat berbelanja di supermarket. Berdasarkan alasan penggunaan, sebagian besar ibu di perdesaan $(86,7 \%)$ maupun di perkotaan $(80,8 \%)$ menggunakan tas belanja karena faktor nonlingkungan.

\section{Sikap terhadap Penggunaan Tas Belanja}

Penelitian pada wilayah desa dan kota menunjukkan ibu setuju bahwa penggunaan tas belanja akan mengurangi sampah plastik. Hasil penelitian tentang sikap menggunakan tas belanja menunjukkan bahwa lebih dari separuh ibu di perdesaan dan perkotaan memiliki sikap terhadap penggunaan tas belanja dalam kategori sedang dengan persentase ibu di perdesaan $(63,3 \%)$ lebih sedikit daripada di perkotaan $(80,0 \%)$. Temuan penelitian juga menegaskan bahwa lebih dari separuh pengguna dan bukan pengguna tas belanja di perdesaan memiliki tingkat sikap terhadap perilaku yang terkategori sedang. Pada wilayah perdesaan, persentase bukan pengguna lebih rendah daripada pengguna tas belanja dengan rincian sebesar 58,1 persen bukan pengguna dan 69,0 persen pengguna. Hal yang sama juga berlaku untuk wilayah perkotaan dengan persentase sebesar 71,4 persen ibu bukan merupakan pengguna dan 84,6 persen merupakan pengguna tas belanja.

Hasil uji beda yang dilakukan menunjukkan bahwa terdapat perbedaan yang nyata antara rata-rata skor sikap penggunaan tas belanja pada ibu diperdesaan dan perkotaan. Ratarata skor indeks sikap penggunaan tas belanja pada ibu di perdesaan lebih rendah daripada di perkotaan dengan rincian sebesar 67,59 untuk wilayah perdesaan dan 72,22 untuk perkotaan. Rata-rata skor indeks sikap ibu tentang penggunaan tas belanja lebih tinggi pada ibu yang bukan pengguna daripada ibu pengguna di perdesaan. Hal ini berbeda dengan wilayah perkotaan, yang menunjukkan tidak adanya perbedaan yang nyata pada sikap terhadap penggunaan tas belanja antara ibu yang bukan pengguna dengan ibu yang pengguna.

\section{Norma Subjektif}

Berdasarkan hasil analisis norma subjektif, lebih dari separuh ibu di perkotaan dan perdesaan memiliki tingkat norma subjektif yang sedang dengan persentase ibu di perdesaan $(61,7 \%)$ lebih sedikit daripada di perkotaan $(62,5 \%)$. Pada wilayah perdesaan, persentase ibu yang bukan pengguna dan memiliki tingkat norma subjektif sedang lebih sedikit dibandingkan dengan ibu yang merupakan pengguna tas belanja dengan rincian masing-masing 45,2 persen untuk bukan pengguna dan 79,3 persen untuk pengguna. Fenomena yang berbeda terjadi di perkotaan, yang mana ibu yang memiliki tingkat norma subjektif kategori sedang lebih tinggi pada ibu yang bukan pengguna daripada pengguna tas belanja. Hasil uji beda menunjukkan adanya perbedaan yang nyata pada rata-rata skor indeks norma subjektif antara ibu di wilayah perdesaan dan perkotaan. Rata-rata skor indeks norma subjektif ibu di wilayah perdesaan lebih rendah daripada wilayah perkotaan dengan rincian 57,46 untuk wilayah perdesaan dan 60,48 untuk perkotaan. Selain itu, hasil uji beda juga menemukan adanya perbedaan yang nyata pada rata-rata skor indeks norma subjektif antara ibu pengguna dan bukan pengguna tas belanja di masing-masing wilayah. Rata-rata skor norma subjektif bukan pengguna lebih rendah daripada pengguna, baik di wilayah perdesaan maupun perkotaan. Pada wilayah perdesaan, skor indeks norma subjektif pada ibu yang bukan pengguna dan pengguna masing-masing 53,76 dan 61,41 ; sedangkan pada wilayah perkotaan masingmasing adalah 54,42 dan 63,74.

\section{Kontrol Perilaku}

Hasil penelitian menunjukkan bahwa lebih dari separuh ibu di wilayah perdesaan dan perkotaan memiliki tingkat kontrol perilaku sedang dengan persentase di perdesaan $(56,7 \%)$ lebih sedikit daripada di perkotaan $(65,0 \%)$. Pada wilayah perdesaan, sekitar lima dari sepuluh ibu yang bukan pengguna tas belanja $(48,0 \%)$ memiliki kontrol perilaku rendah. Hasil uji beda menunjukkan adanya perbedaan yang nyata pada rata-rata skor indeks kontrol perilaku ibu di wilayah perdesaan dan kota. Rata-rata skor indeks kontrol perilaku ibu di perdesaan lebih rendah daripada di perkotaan dengan rincian masingmasing 59,44 untuk perdesaan dan 64,86 untuk perkotaan. 
Sementara itu, sekitar tujuh dari sepuluh ibu yang menggunakantas belanja $(69,0 \%)$ memiliki kontrol perilaku yang sedang. Pada wilayah perkotaan, sekitar tujuh dari sepuluh ibu yang tidak menggunakan tas belanja $(71,4 \%)$ dan enam dari sepuluh ibu yang menggunakan tas belanja $(61,5 \%)$ mempunyai kontrol perilaku pada kategori sedang. Hasil penelitian menunjukkana adanya perbedaan yang nyata pada kontrol perilaku antara ibu bukan pengguna dan pengguna tas belanja baik di perdesaan maupun perkotaan. Rata rata skor indeks kontrol perilaku pada ibu bukan pengguna lebih rendah dibandingkan pada ibu pengguna tas belanja dengan masing-masing skor adalah 55,91 dan 63,22 di wilayah perdesaan. Pada wilayah perkotaan, rata-rata skor indeks kontrol perilaku ibu yang tidak menggunakan tas belanjajuga lebih rendah dibandingkan dengan ibu yang menggunakan tas belanja dengan masingmasing skor 59,92 dan 67,52.

\section{Niat}

Beberapa ibu di desa dan kota memiliki niat membawa tas belanjanya masih tergolong cukup baik. Hasil penelitian menemukan bahwa lebih dari proporsi terbesar ibu di wilayah perdesaan dan perkotaan memiliki niat untuk menggunakan tas belanja pada pada kategori sedang dengan persentase pada wilayah perdesaan $(66,7 \%)$ lebih sedikit daripada perkotaan $(70,0 \%)$. Pada wilayah perdesaan, lebih dari separuh ibu memiliki niat yang terkategori sedang dengan persentase sebesar 61,3 persen pada ibu bukan pengguna tas belanja dan 72,4 persen ibu pengguna tas belanja. Hal yang sama berlaku pada wilayah perkotaan. Ibu yang memiliki niat menggunakan tas belanja pada kategori sedang, lebih tinggi proporsinya pada ibu yang tidak menggunakan tas belanja $(71,4 \%)$ dibandingkan dengan proporsi ibu yang menggunakan tas belanja $(69,2 \%)$.

Hasil uji beda menunjukkan adanya perbedaan yang nyata pada rata-rata skor indeks niat ibu menggunakan tas belanja antara ibu-ibu tidak bekerja wilayah perdesaan dan perkotaan; dengan skor di perdesaan $(59,55)$ lebih rendah daripada skor di perkotaan $(62,00)$. Perbedaan yang nyata juga terdapat pada rata-rata skor indeks niat ibu menggunakan tas belanja antara ibu bukan pengguna dan pengguna baik di wilayah perdesaan maupun perkotaan. Rata-rata skor niat menggunakan tas belanja pada ibu bukan pengguna rendah daripada ibu pengguna di kedua wilayah. Pada wilayah perdesaan, rata-rata skor indeks niat menggunakan tas belanja pada kelompok ibu bukan pengguna tas belanja $(56,13)$ lebih rendah dari rata-rata capaian ibu pengguna $(63,22)$. Sementara itu, di perkotaan juga menunjukkan fenomena yang sama yang mana rata-rata skor niat menggunakan tas belanja pada ibu bukan pengguna lebih rendah $(54,76)$ dibandingkan dengan ibu pengguna $(65,90)$.

\section{Faktor - faktor yang Memengaruhi Niat lbu Tidak Bekerja dalam Menggunakan Tas Belanja}

Berdasarkan hasil model regresi yang dihasilkan dalam penelitian ini sesuai dengan yang tersaji pada Tabel 1, hanya kontrol perilaku yang memiliki pengaruh positif signifikan terhadap niat untuk menggunakan tas belanja pada pengguna jika variabel bebas yang digunakan adalah karakteristik ibu, sikap terhadap penggunaan tas belanja, norma subjektif, dan kontrol perilaku. Koefisen regresi menunjukkan bahwa kenaikan satu satuan variabel kontrol perilaku akan menaikkan nilai dari variabel niat sebesar 0.768 .

Secara keseluruhan, model regresi yang diuji dan dihasilkan dari pada uji pengaruh terhadap niat menggunakan tas belanja pada kelompok bukan pengguna menunjukkan bahwa sebesar 44,3 persen niat menggunakan tas belanja dapat dijelaskan oleh variabel bebas pada model, yaitu wilayah, karakteristik ibu, sikap terhadap perilaku, norma subjektif, dan kontrol perilaku, sedangkan sisanya sebesar 55,7 persen dijelaskan oleh variabel yang tidak diteliti.

Tabel 1 Koefisien regresi karakteristik ibu, sikap terhadap perilaku, norma subjektif, kontrol perilaku terhadap niat pada pengguna $(n=55)$

\begin{tabular}{|c|c|c|c|}
\hline \multirow{2}{*}{ Variabel } & \multicolumn{3}{|c|}{ Niat pada pengguna } \\
\hline & $B$ & $\beta$ & Sig. \\
\hline Konstanta & 10,773 & & 0,357 \\
\hline Domisili & $-1,353$ & $-0,072$ & 0,573 \\
\hline Usia (tahun) & $-0,112$ & $-0,142$ & 0,237 \\
\hline Pendidikan (tahun) & $-0,159$ & $-0,062$ & 0,599 \\
\hline Pendapatan (Rp) & $5,109 \mathrm{E}-7$ & 0,077 & 0,497 \\
\hline $\begin{array}{l}\text { Sikap terhadap } \\
\text { perilaku (indeks) }\end{array}$ & 0,204 & 0,169 & 0,256 \\
\hline $\begin{array}{l}\text { Norma subjektif } \\
\text { (indeks) }\end{array}$ & $-0,077$ & $-0,059$ & 0,636 \\
\hline $\begin{array}{l}\text { Kontrol perilaku } \\
\text { (indeks) }\end{array}$ & 0,768 & 0,681 & $0,000^{* *}$ \\
\hline Adjusted $\mathrm{R}^{2}$ & & 0.443 & \\
\hline Sig. & & $0.000^{* *}$ & \\
\hline
\end{tabular}




\section{Faktor - faktor yang Memengaruhi Perilaku Penggunaan Tas Belanja}

Selanjutnya, penelitian ini menguji pengaruh variabel bebas terhadap perilaku penggunaan tas belanja yang hasil model regresinya tersaji pada Tabel 2. Berdasarkan model regresi yang dihasilkan, dapat disimpulkan bahwa terdapat pengaruh yang positif signifikan pada variabel norma subjektif, kontrol perilaku, dan niat terhadap frekuensi penggunaan tas belanja.

Koefisien regresi menunjukkan bahwa peningkatan satu satuan norma subjektif meningkatkan peluang frekuensi penggunaan tas belanja sebesar 0,103; peningkatan satu satuan kontrol perilaku meningkatkan peluang frekuensi penggunaan tas belanja sebesar 0,198 ; peningkatan satu satuan niat meningkatkan peluang 0,064 kali lebih besar untuk sering menggunakan tas belanja. Sementara itu sikap ibu terhadap penggunaan tas belanja berpengaruh negatif terhadap frekuensi penggunaan tas belanja. Hasil model regresi menunjukkan bahwa peningkatan satu satuan sikap terhadap penggunaan tas belanja akan menurunkan peluang untuk memakai tas belanja sebesar 0,101.

Secara keseluruhan, model uji pengaruh variabel bebas terhadap frekuensi penggunaan tas belanja menunjukkan bahwa sebesar 33,6 persen frekuensi penggunaan tas belanja dapat dijelaskan oleh variabel pada model, yaitu karakteristik ibu, sikap terhadap perilaku, norma subjektif, kontrol perilaku, dan niat, sedangkan sisanya sebesar 66,4 persen dijelaskan oleh variabel yang tidak diteliti.

Tabel 2 Koefisien regresi logistik variabel karakteristik ibu, sikap terhadap perilaku, norma subjektif, kontrol perilaku, dan niat terhadap perilaku

\begin{tabular}{|c|c|c|c|}
\hline Variabel & B & $\begin{array}{l}\text { Exp } \\
\text { (B) }\end{array}$ & Sig. \\
\hline Wilayah & 0,135 & 1,145 & \\
\hline Usia (tahun) & $-0,012$ & 0,988 & 0,576 \\
\hline Pendidikan (tahun) & $-0,054$ & 0,9474 & 0,463 \\
\hline Pendapatan (Rp) & $8,305 \mathrm{E}-8$ & 1,000 & 0,617 \\
\hline $\begin{array}{l}\text { Sikap terhadap } \\
\text { perilaku (indeks) }\end{array}$ & $-0,101$ & 0,904 & $0,014^{* *}$ \\
\hline $\begin{array}{l}\text { Norma subjektif } \\
\text { (indeks) }\end{array}$ & 0,103 & 1,108 & $0,002^{\star \star}$ \\
\hline $\begin{array}{l}\text { Kontrol perilaku } \\
\text { (indeks) }\end{array}$ & 0,198 & 1,219 & $0,000^{* \star}$ \\
\hline Niat (indeks) & 0,064 & 1,097 & $0,031^{* *}$ \\
\hline $\begin{array}{l}\text { Koefisien } \\
\text { Nagelkerke }\end{array}$ & & 0,336 & \\
\hline Sig. & & $0,000^{* *}$ & \\
\hline
\end{tabular}

\section{PEMBAHASAN}

Perilaku prolingkungan seperti perilaku penggunaan tas belanja dapat dijelaskan dengan baik menggunakan Theory of Planned Behavior seperti pada hasil penelitian Greaves et al. (2013); Chao dan Lam (2011); dan Nigbur et al. (2010). Theory of Planned Behavior merupakan teori yang menekankan pada niat sebagai mediator langsung yang memengaruhi perilaku dan menekankan adanya pengaruh sikap terhadap perilaku, norma subjektif, dan kontrol perilaku terhadap niat (Ajzen, 1991; 2002). Hasil dari penelitian ini menemukan bahwa perilaku penggunaan tas belanja pada ibu tidak bekerja ditentukan oleh sikap ibu terhadap penggunaan tas belanja, norma subjektif, kontrol perilaku, dan niat ibu. Temuan penelitian menegaskan bahwa semakin ibu berniat menggunakan tas belanja dan merasakan adanya dukungan dan kontrol untuk memakai tas belanja maka semakin tinggi kemungkinan ibu untuk meningkatkan frekuensi penggunaan tas belanja. Hasil ini sejalan dengan penelitian Klöckner (2013) yang menunjukkan bahwa perilaku pembelian yang proingkungan dipengaruhi oleh niat konsumen. Namun demikian, hasil penelitian ini juga menemukan bahwa sikap terhadap penggunaan tas belanja berpengaruh negatif terhadap frekuensi penggunaan tas belanja pada ibu bekerja. Hal ini dikarenakan terdapat pengaruh dari variabel lain karena hasil uji regresi menunjukkan tidak adanya pengaruh antara variabel sikap terhadap penggunaan tas belanja dan frekuensi penggunaan tas belanja dan hasil analisis lebih lanjut menyatakan pengaruh yang positif terhadap frekuensi penggunaan tas belanja jika variabel lain dieliminasi. Perlu adanya identifikasi lebih lanjut untuk mengetahui variabel yang berpengaruh terhadap variabel sikap terhadap penggunaan tas belanja.

Hasil kajian terdahulu menekankan bahwa niat dipengaruhi oleh sikap terhadap perilaku, norma subjektif, dan kontrol perilaku (Ajzen, 1991; 2002). Hasil penelitian ini menemukan bahwa hanya variabel kontrol perilaku yang berpengaruh positif signifikan terhadap niat menggunakan tas belanja. $\mathrm{Hal}$ ini menunjukkan bahwa meskipun ibu menganggap penggunaan tas belanja sebagai sesuatu yang baik dan terdapat dukungan dari orang sekitar, ibu tidak akan berniat menggunakan tas belanja jika ibu tidak merasa bisa dan terdapat hambatan situasional. Persepsi ibu mengenai mudah atau sulitnya menggunakan tas belanja berpengaruh 
terhadap niat menggunakan atau tidak menggunakan tas belanja. Hasil analisis lebih lanjut juga menemukan bahwa pada pengguna tas belanja, faktor yang paling berpengaruh adalah kontrol mereka untuk membawa tas belanja. Hal ini sejalan dengan studi Hasan (2015) dan Ando et al. (2010) yang menemukan bahwa niat untuk berperilaku ramah lingkungan di pengaruhi secara positif signifikan oleh kontrol perilaku

Penelitian ini mengungkapkan adanya pengaruh kontrol perilaku namun tidak mengungkapkan pengaruh dari sikap terhadap perilaku dan norma subjektif terhadap niat. Menurut Ajzen dan Fishbein, (2005), kontrol perilaku mengambil peran yang lebih besar ketika masalah kontrol aktual dihubungkan dengan performa perilaku. Ketika konsumen dihadapkan pada kondisi yang mana semakin banyak faktor pendukung yang dirasakan dan semakin sedikit faktor penghambat yang dirasakan, maka semakin besar kontrol yang konsumen rasakan atas perilaku tersebut dan begitu juga sebaliknya (Ajzen 1985; 2002). Penelitian ini sejalan dengan penelitian terdahulu yang menemukan bahwa sikap, norma subjektif, dan perhatian terhadap lingkungan tidak dapat memprediksi niat untuk menggunakan tas belanja (Lam \& Chen, 2006) serta perilaku prolingkungan lainnya (Whitmarsh L \& O'Neill S, 2010). Berdasarkan hal tersebut,kontrol perilaku memainkan peran penting dalam menentukan niat untuk menggunakan tas belanja

Keakuratan dalam mengukur perilaku penggunaan tas belanja juga dapat dilihat dari hubungan antara variabel demografi dan variabel dalam perspektif TPB yang digunakan dalam penelitian ini. Hasil identifikasi karakteristik ibu menunjukkan bahwa hampir separuh ibu termasuk dalam kategori usia dewasa madya dan sepertiganya merupakan lulusan SD dan SMA. Penelitian ini mengungkapkan bahwa semakin tinggi pendidikan ibu maka semakin baik pula sikap yang dimilikinya terhadap perilaku penggunaan tas belanja. Temuan ini sejalan dengan penelitian Dietz et al. (1998); Whitmarsh dan O'Neill (2010) yang menyatakan bahwa variabel demografis, salah satunya pendidikan, mempunyai hubungan signifikan dengan perilaku terkait lingkungan. Namun demikian, pada penelitian ini variabel demografis lainnya seperti usia dan pendapatan tidak memiliki hubungan yang positif signifikan dengan variabel sikap terhadap perilaku, norma subjektif, kontrol perilaku, dan niat menggunakan tas belanja.
Hasil analisis menemukan bahwa sebagian besar ibu memiliki tingkat sikap terhadap penggunaan tas belanja, norma subjektif, kontrol perilaku, dan niat yang termasuk dalam kategori sedang. Ibu yang berada di wilayah perkotaan lebih memiliki sikap yang positif dan menganggap membawa tas belanja mudah dilakukan. Penelitian Huddart-Kennedy et al. (2009) menyebutkan bahwa terdapat perbedaan sikap terhadap perilaku prolingkungan antara penduduk wilayah perdesaan dan perkotaan. lbu yang menggunakan tas belanja terbukti memiliki dukungan, kemudahan, dan niat membawa tas belanja lebih tinggi dibandingkan yang tidak menggunakan tas belanja meskipun keduanya memiliki sikap yang baik terhadap penggunaan tas belanja.

Berdasarkan hasil penelitian, separuh ibu di wilayah perdesaan dan sepertiga ibu di perkotaan tidak membawa tas belanja ketika berbelanja. Hal ini dapat disebabkan oleh ibu sering lupa untuk membawa tas belanja, seperti yang ditunjukkan oleh sebaran jawaban pada variabel kontrol perilaku. Jumlah bukan pengguna yang terdapat di perkotaan lebih sedikit dan diduga karena supermarket yang berada di wilayah perkotaan secara aktif mendorong ibu untuk menggunakan tas belanja. Hasil uji deskriptif lebih lanjut menemukan bahwa jumlah pengguna tas belanja lebih sedikit dari jumlah ibu yang memiliki tas belanja. Hal ini berarti meskipun ibu memiliki tas belanja, tidak semua ibu menggunakannya ketika berbelanja. Pada pengguna tas belanja, setengah proporsinya memakai tas belanja sejak tahun 2016. Pada tahun ini, pemerintah berusaha menekan jumlah penggunaan kantung plastik dengan menetapkan kebijakan kantung plastik berbayar yang pelaksanaannya melalui tahap uji coba selama satu bulan. Adanya kebijakan plastik berbayar mendorong konsumen untuk menggunakan tas belanja. Pemerintah memiliki peran untuk mendorong penggunaan tas belanja. Penelitian Yeow et al. (2014) yang dilakukan di Inggris juga menunjukkan hasil adanya peningkatan penggunaan tas belanja ketika pemerintah berkerja sama dengan supermarket dalam mengurangi penggunaan plastik satu kali pakai.

Pihak lain yang memiliki peran penting untuk mendorong penggunaan tas belanja adalah supermarket dan media. Hal ini ditunjukkan dari hasil penelitian yang menyatakan bahwa informasi mengenai tas belanja didapatkan dari supermarket dan media. Hal ini sejalan dengan hasil penelitian Yeow et al. (2014) 
yang menyatakan bahwa sumber informasi utama mengenai tas belanja berasal dari supermarket. Supermarket juga menjadi tempat utama digunakannya tas belanja terutama untuk ibu yang berada di perkotaan. Namun demikian, motivasi ibu dalam menggunakan tas adalah alasan yang tidak terkait dengan lingkungan. Sebagian besar ibu menggunakan tas belanja karena merasa tas belanja lebih efisien, hemat, tahan lama, dan memiliki kapasitas yang lebih besar. Hal ini berbeda dengan penelitian terdahulu yang dilakukan Yeow et al. (2014) di Inggris yang menyatakan motivasi pengguna sebagian besar adalah untuk menyelamatkan lingkungan.

Melalui penelitian ini, diharapkan dapat memberikan gambaran mengenai perilaku penggunaan tas belanja saat ini. Temuan dalam penelitian ini diharapkan dapat menjadi bukti empiris tentang pentingnya membangun kontrol perilaku, sikap, dan norma subjektif sehingga mampu mendorong konsumen untuk berniat dan menggunakan tas belanja sehinggapengurangan konsumsi kantung plastik yang tidak ramah lingkungan dapat dioptimalkan.

\section{SIMPULAN DAN SARAN}

Perilaku penggunaan tas belanja merupakan salah satu perilaku ramah lingkungan yang harus didorong untuk mengatasi permasalahan lingkungan terkait sampah plastik. Berdasarkan hasil penelitian, sebagian besar contoh merupakan ibu rumah tangga yang termasuk dalam kategori usia dewasa madya, memiliki pendidikan hingga jenjang SMA, dan memiliki pendapatan Rp1.000.000,00 Rp2.000.000,00. Niat menggunakan tas belanja pada ibu rumah tangga termasuk dalam kategori sedang, begitu pula dengan sikap terhadap penggunaan tas belanja, norma subjektif dan kontrol perilaku yang dimiliki. Hasil uji beda menunjukan bahwa ibu yang berada di wilayah perkotaan memiliki sikap terhadap perilaku dan kontrol perilaku yang lebih tinggi. Pengguna memiliki norma subjektif, kontrol perilaku, dan niat yang lebih tinggi. Hasil uji regresi memperlihatkan bahwa faktor yang berpengaruh positif terhadap perilaku penggunaan tas belanja adalah niat, norma subjektif, dan kontrol perilaku sedangkan sikap terhadap penggunaan tas belanja berpengaruh secara negatif terhadap perilaku penggunaan tas belanja. Niat ibu untuk membawa tas belanja dipengaruhi secara positif oleh kontrol perilaku yang dimiliki ibu.
Berdasarkan hasil penelitian, kontrol perilaku berpengaruh terhadap niat penggunaan tas belanja. Oleh karena itu, hambatan situasional perlu diperhatikan disamping mengkampanyekan dampak positif tas belanja bagi lingkungan karena masyarakat masih kesulitan menggunakan tas belanja disebabkan oleh faktor situasional. Supermarket dan pasar dapat mendorong penggunaan tas belanja dengan memberikan informasi dan menyediakan kemudahan terhadap akses tas belanja. Pemerintah dapat mendorong penggunaan tas belanja melalui media dengan menyelipkan pesan lingkungan pada kampanye iklan layanan masyarakat agar dapat meningkatkan pengetahuan masyarakat mengenai lingkungan. Konsumen dapat didorong menggunakan tas belanja dengan membiasakan diri menyimpan tas belanja di tempat yang mudah dijangkau. Penelitan selanjutnya sebaiknya memperluas lingkup sampel karena penggunaan tas belanja tidak terbatas pada ibu rumah tangga yang tidak bekerja dengan melibatkan variabel pengetahuan terhadap lingkungan dan dilakukan pada lokasi yang memungkinkan untuk melakukan observasi perilaku secara langsung.

\section{DAFTAR PUSTAKA}

[Ditjen pslb3] Direktorat Jenderal Pengelolaan Sampah, Limbah, dan B3. 2016. Kebijakan Kantung Belanja Pastik Tidak Gratis. Jakarta(ID): KLHK

Ajzen, I. (1985). From intentions to actions: A theory of planned behavior. In Action control (pp. 11-39). Springer Berlin Heidelberg.

(1991). The theory of planned behavior. Organizational Behavior and Human Decision Processes, 50(2), 179211.

. (2002). Perceived behavioral control, self-efficacy, locus of control, and the theory of planned behavior. Journal of applied social psychology, 32(4), 665683.

.(2006). Constructing a theory of planned behavior questionnaire: Conceptual and methodological consideration [internet]. 05 Februari 2018.

Ajzen, I., \& Fishbein, M. (2005). The Influence Of Attitudes On Behavior. The handbook of attitudes. Edited by: Albarracín D, Johnson BT, Zanna MP. 
Ando, K., Ohnuma, S., Blöbaum, A., Matthies, E., \& Sugiura, J. (2010). Determinants of individual and collective proenvironmental behaviors: Comparing Germany and Japan. Journal Of Environmental Information Science, 38(5), 21-32.

Berenguer, J., Corraliza, J. A., \& Martín, R. (2005). Rural-Urban differences in environmental concern, attitudes, and actions. European Journal of Psychological Assessment, 21(2), 128138.

Chao, Y. L., \& Lam, S. P. (2011). Measuring responsible environmental behavior: Self-reported and other-reported measures and their differences in testing a behavioral model. Environment and Behavior, 43(1), 53-71.

Chen, X., Peterson, M. N., Hull, V., Lu, C., Lee, G. D., Hong, D., \& Liu, J. (2011). Effects of attitudinal and sociodemographic factors on pro-environmental behaviour in urban China. Environmental Conservation, 38(1), 45-52.

Dewi, F., \& Yusalina. (2011). Aplikasi Theory of Planned Behavior pada analisis perilaku konsumen beras organik di Kota Bogor. Prosiding Seminar Penelitian Unggulan Departemen Agribisnis, 97115

Dietz, T., Stern, P. C., \& Guagnano, G. A. (1998). Social structural and social psychological bases of environmental concern. Environment and Behavior, 30(4), 450-471.

Gamerman, E. (2008). An Inconvenient Bag. The Wall Street Journal, Diakses dari http://www.wsj.com/articles/SB12223842 2541876879,pada 01 April 2017

Greaves, M., Zibarras, L. D., \& Stride, C. (2013). Using the theory of planned behavior to explore environmental behavioral intentions in the workplace. Journal of Environmental Psychology, 34, 109-120.

Handayani, S. D. (2011). Theory of Planned Behavior: aplikasi pada konsumen rumah sakit. Jurnal Manajemen \& Bisnis, 1(2): 146-158

Han, H., Hsu, L. T. J., \& Sheu, C. (2010). Application of the theory of planned behavior to green hotel choice: Testing the effect of environmental friendly activities. Tourism Management, 31(3), 325-334.
Hasan, S. N. M. S., Harun, R., \& Hock, L. K. (2015). Application of theory of planned behavior in measuring the behavior to reduce plastic consumption among students at Universiti Putra Malaysia, Malaysia. Procedia Environmental Sciences, 30, 195-200.

Huddart-Kennedy, E., Beckley, T. M., McFarlane, B. L., \& Nadeau, S. (2009). Rural-urban differences in environmental concern in Canada. Rural sociology, 74(3), 309-329.

Hurlock, E. B., Istiwidayanti, Sijabat, R. M., \& Soedjarwo. (1990). Psikologi Perkembangan: Suatu Pendekatan Sepanjang Rentang Kehidupan. Erlangga, Jakarta.

Jambeck, J. R., Geyer, R., Wilcox, C., Siegler, T. R., Perryman, M., Andrady, A., \& Law, K. L. (2015). Plastic waste inputs from land into the ocean. Science, 347(6223), 768-771.

Karmarkar, U. R., \& Bollinger, B. (2015). BYOB: How bringing your own shopping bags leads to treating yourself and the environment. Journal of Marketing, 79(4), 1-15.

Klöckner, C. A. (2013). A comprehensive model of the psychology of environmental behavior-A meta-analysis. Global Environmental Change, 23(5), 1028-1038.

Kusumo, R. A. B., Charina, A., Sukayat, Y., Mukti, G. W. (2017). Kajian edukasi ramah lingkungan dan karakteristik konsumen serta pengaruhnya terhadap sikap dan perilaku ramah lingkungan. Jurnal IImu Keluarga dan Konsumen. 10(3):238-249

DOI: http://dx.doi.org/10.24156/jikk.2017.10.3. $\underline{238}$

Lam, S. P., \& Chen, J. K. (2006). What makes customers bring their bags or buy bags from the shop? A survey of customers at a Taiwan hypermarket. Environment and Behavior, 38(3), 318-332.

Laudenslager, M. S., Holt, D. T., \& Lofgren, S. T. (2004). Understanding air force members' intentions to participate in proenvironmental behaviors: An application of the theory of planned behavior. Perceptual and motor skills, 98(3_suppl), 1162-1170.

Nawangpalupi, C. B., Pratiwi, L., Herawati, Y. (2011). Evaluasi Perubahan Perilaku Dalam Penggunaan Tas Belanja 
Pengganti Kantung Plastik. Di dalam: Nawangpalupi C B, editor. Proceeding Seminar Nasional Industrial Services [Internet].[Waktu dan tempat pertemuan tidak diketahui]. Bandung (ID): Universitas Katolik Parahyangan. HIm 66-71; [diunduh 2016 Desember 27]. Tersedia pada: http://www.academia.edu/3832382/Evalu asi_Perubahan_Perilaku_Dalam_Pengg unaan_Tas_Belanja_Pengganti_Kantun g_Plastik

Nigbur, D., Lyons, E., \& Uzzell, D. (2010). Attitudes, norms, identity and environmental behaviour: using an expanded theory of planned behaviour to predict participation in a kerbside recycling programme. British Journal of Social Psychology, 49(2), 259-284.

Ohtomo, S., \& Ohnuma, S. (2014). Psychological interventional approach for reduce resource consumption: reducing plastic bag usage at supermarkets. resources, Conservation and Recycling, 84, 57-65.

Pratiwi, N. A., Hartoyo. (2014). Analisis niat beli asuransi jiwa pada mahasiswa: aplikasi Theory of Planned Behavior. Jurnal IImu Keluarga dan Konsumen, 7(1): 58-66, DOI: http://dx.doi.org/10.24156/jikk.2014.7.1.5 8

Purwaningrum, P. (2016) Upaya mengurangi timbulan sampah plastik di lingkungan. JTL. 8(2):141-147

Setyowati, R., Mulasari, S.A. (2013). Pengetahuan dan perilaku ibu rumah tangga dalam pengelolaan sampah plastik. Kesmas: National Public Health Journal. 7(12): 562-566.

Steg, L., \& Vlek, C. (2009). Encouraging proenvironmental behaviour: an integrative review and research agenda. Journal of environmental psychology, 29(3), 309317.

Surono, U. B. (2013). Berbagai metode konversi sampah plastik menjadi bahan bakar minyak. Jurnal Teknik. 3(1): 32-40

Teng, P. K., Rezai G., Mohamed Z., \& Shamsudin, M. N. (2012). Factors influencing public intention towards purchasing green food in Malaysia. OIDA International Journal of Sustainable Development, 4(2), 51-60.

Wahid, N. A., Rahbar E., \& Shyan, T. S. (2011). Factors influencing the green purchase behavior of Penang environmental volunteers. International Business Management, 5, 38-49.

Whitmarsh, L., \& O'Neill, S. (2010). Green identity, green living? The role of proenvironmental self-identity in determining consistency across diverse proenvironmental behaviours. Journal of Environmental Psychology, 30(3), 305314.

Wijaya, T. (2017). Nilai orientasi alami manusia dan pengetahuan organik sebagai determinan perilaku beli pangan organik. Jurnal Siasat Bisnis, 21(2), 107-126. Doi: http://dx.doi.org/10.20885/jsb.vol21.iss2. art5.

Yeow, P., Dean, A., \& Tucker, D. (2014). Bags for life: The embedding of ethical consumerism. Journal of Business Ethics, 125(1), 87-99. 